\title{
Regime shifts and ecosystem services in Swedish coastal soft bottom habitats: when resilience is undesirable
}

\author{
Max Troell ${ }^{1}$, Leif Pihl, Patrik Rönnbäck, Håkan Wennhage, Tore Söderqvist, and Nils Kautsky
}

\begin{abstract}
Ecosystems can undergo regime shifts where they suddenly change from one state into another. This can have important implications for formulation of management strategies, if system characteristics develop that are undesirable from a human perspective, and that have a high resistance to restoration efforts. This paper identifies some of the ecological and economic consequences of increased abundance of filamentous algae on shallow soft bottoms along the Swedish west coast. It is suggested that a successive increase in the sediment nutrient pool has undermined the resilience of these shallow systems. After the regime shift has occurred, self-generation properties evolve keeping the system locked in a highdensity algae state. The structural and functional characteristics of the new system state differ significantly from the original one, resulting in less valuable ecosystem goods and services generated for society. In Sweden, loss of value results from the reduced capacity for mitigating further coastal eutrophication, reduced habitat quality for commercial fishery species, and the loss of aesthetic and recreational values.
\end{abstract}

Key Words: alternate stable states; shallow soft bottoms; eutrophication; filamentous algal mats; resilience; ecosystem function; ecosystem goods and services.

\section{INTRODUCTION}

Many coastal marine ecosystems worldwide are subject to increased supply of nutrients from direct point discharges (sewage, industries, etc.), terrestrial run-off, and atmospheric deposition. Nitrogen loading in the Skagerrak and Kattegat regions on the Swedish west coast has increased about four-fold since 1930 (Rosenberg et al. 1990, Aure et al. 1996, Rosenberg et al. 1996). A small tidal amplitude, generally less than $20 \mathrm{~cm}$, makes the coastal zone and, especially the inner archipelago, sensitive to increased nutrient loading. Phytoplankton production has doubled, from around $100 \mathrm{~g}-\mathrm{C}-\mathrm{m}^{-2}-\mathrm{y}^{-1}$ in the $1950 \mathrm{~s}$ and $1960 \mathrm{~s}$, to $200 \mathrm{~g}-\mathrm{C}-\mathrm{m}^{-2}-\mathrm{y}^{-1}$ during the period of 1980 to 2000 (Richardsson and Heilman 1995, Lindahl 2003). Over the same time period, coastal sedimentation has increased about five-fold, from 30 to $140 \mathrm{~g}$-C$\mathrm{m}^{-2}-\mathrm{y}^{-1}$ (Lindahl 2003). Observed indications of eutrophication include increased frequencies of phytoplankton blooms and reductions of oxygen in bottom waters (Baden et al. 1990), as well as an increased occurrence of filamentous algae on shallow soft bottoms along the Swedish west coast (Afzelius 1978, Wennberg 1987, Österling and Pihl 2001). The average cover of green algal mats in 10 shallow (0-1 m) bays on the Swedish Skagerrak Coast, increased significantly from $<3 \%$ during the period of 1976 to 1978 , to $40 \%$ in 1992 to 1994 (Pihl et al. 1995). From 1994 to 1996 , the distribution of algal mats was monitored by aerial photography in shallow (0-1 m) soft bottom areas along $200 \mathrm{~km}$ of the Swedish Skagerrak Coast, and the average cover of green algal mats ranged from 30 to $50 \%$ of the total shallow soft bottom habitat in the archipelago (Pihl et al. 1999).

Resilience is the ability of a social-ecological system to undergo, absorb, and respond to change and disturbance, while maintaining its functions and controls (Carpenter et al. 2001). The definition of resilience includes three equally important aspects: (1) the ability of the system to resist a disturbance so that it is not overwhelmed, but instead retains its functions, (2) the capability of the system for self- 
organization (endogenous reorganization), and (3) the ability to learn from and incorporate disturbances (mechanisms for adaptive capacity) (Carpenter 2001). Loss of resilience is not necessarily a noticeable gradual degradation, but can be a sudden shift triggered by a stochastic event or when a threshold is suddenly reached (Scheffer et al. 2001, Dent et al. 2002, Scheffer and Carpenter 2003, Petraitis and Dudgeon 2004). Until then, the system may not give any indication of vulnerability, particularly if we monitor the flows of ecosystem goods and services (e.g., fish productivity). Since the theory of multiple states was first developed (May 1977), a number of examples of alternative states have appeared in the literature (see references in Folke et al. 2005).

This paper identifies two alternative system states of shallow soft sediment along the Swedish west coast. The main aim is to increase our understanding about how the generation of ecosystem goods and services differ between the two system states. In addition, we describe structural and functional changes, identify main system drivers, and discuss inherent self-generating properties from a resilience perspective.

\section{STRUCTURE AND FUNCTIONS OF COASTAL SHALLOW SOFT BOTTOM ECOSYSTEM}

Soft bottom sediments constitute $>70 \%$ of the shallow zone (0-1 m) along the Swedish west coast (Pihl and Rosenberg 1982). This habitat is usually free from macrovegetation, but in some areas a patchy coverage of the macrophytes Zostera marina and Ruppia sp. or macroalgae, such as Fucus spp., exists. This is a key coastal ecosystem because of its wide distribution and its role in sustaining important ecological functions. The main energy source for the shallow soft bottom system is primary production imported from pelagic phytoplankton (Möller et al. 1985). Phytoplankton is utilized by filter-feeders and deposit-feeders, which capture and transfer energy to other benthic and epibenthic organisms, including fish (Cloern 1982, Officer et al. 1982, Loo and Rosenberg 1989). In addition, microphytobenthic algae attached to sediment particles make a significant contribution to the primary production of the shallow system (Sundbäck et al. 1990).

Soft sediment bottoms are characterized by a high infauna and epibenthic fauna production (Pihl and Rosenberg 1982, Möller et al. 1985). The high food production and reduced predation pressure from deep water fish make the shallow soft bottom ideal nursery grounds for many commercial species of fishes (Zijlstra 1972, Gibson 1994). Flatfishes such as plaice, flounder, sole, turbot, and brill, settle as larvae on sandy beaches and stay as juveniles for several months in shallow $(<3 \mathrm{~m})$ waters (Pihl 1989). Growth and survival of the juvenile flatfishes are significantly higher on the shallow soft bottoms compared to other alternative habitats, and such areas are therefore considered as essential in the life cycle of these species (Gibson 1994). Juvenile gadoids (codfish) and clupeids (herring) use the shallow habitats as feeding grounds, and undertake seasonal or diurnal foraging migrations to utilize the rich production of the sandy beaches (Pihl and Wennhage 2002, Wennhage and Pihl 2002).

Shallow soft bottoms also play an important role in the carbon and nutrient dynamics of coastal systems. Particulate organic material and plankton from the surface waters accumulate in shallow soft bottom sediment during the summer. Some of this carbon is available for consumption by benthic microbes, meio- and macrofauna in the system, and can either be buried in the sediment or transferred out of the system via physical exports, migration of mobile species, or predatory fish. Möller et al. (1985) estimated that $50-75 \%$ of the production of the benthic fauna is consumed by epibenthic predators during most years, and that approximately $90 \%$ of the production of these predators is exported to deeper waters during late autumn. Micro-organisms in the sediments also take part in the transfer process by mineralization of organic matter.

\section{ALTERNATIVE SYSTEM STATE - NET CHANGES IN ECOSYSTEM GOODS AND SERVICES}

The formation of algal mats in shallow areas results in considerable changes in ecosystem structure and functions, many of which are important for the generation of ecosystem goods and services. We will here concentrate on the net effect on three groups of ecosystem services: (1) mitigation of eutrophication, (2) seafood production, and (3) aesthetic and recreational values (Table 1). These ecosystem services were selected on the basis of their substantial socio-economic importance as well as the availability of background data. 
Table 1. Net changes in the provision of ecosystem services after phase shift from unvegetated to algal mat covered shallow soft bottom habitats on the Swedish west coast.

\begin{tabular}{l}
\hline \hline Key parameter* \\
\hline - Water circulation \\
(reduced) \\
- Sedimentation and \\
accumulation of organic \\
matter (increased) \\
- Oxygen levels in water \\
and sediment (reduced) \\
- Abundance of \\
suspension and surface \\
deposit feeder (reduced) \\
- Oxygen level in water \\
column
\end{tabular}

SEA column

Key ecosystem services $\quad$ Net change $\quad$ Spatial scales affected**

Key ecosystem services

MITIGATION OF
EUTROPHICATION

\section{Denitification}

Mineralisation transfer to higher trophic levels
Efficient energy

local regional international

local regional international

- Mechanical prevention of larval immigration

- Foraging efficiency for fish

- Abundance of food organisms

- Visual cover of algal mats

- Physical disturbance on recreational activities

- Smell of decomposing algae
SOCIAL AND CULTURAL Aesthetic attraction SERVICES
Quality as nursery, feeding and breeding habitat for fishery species of commercial and recreational value

* Changes from algal mat cover within brackets.

** Describing on what scale the change in ecosystem service is relevant, i.e. accounting for distribution of user groups and service of more global concern.

\section{Mitigation of eutrophication}

Bays with recurrent algal mats on the Swedish west coast have an average organic carbon and nitrogen sediment content that is three times higher than algae-free bays (Pihl et al. 1999, Svensson and Pihl
2001). Besides localized nutrient inputs, elevated nutrients can be explained by increased sedimentation due to reduced water circulation caused by algal mats, and by the algae acting as mechanical filters for organic matter in the water column. Furthermore, parts of the algal mats 
decompose during the summer season and as much as $50 \%$ of the annual production can be incorporated in the sediment when dead algae accumulate (Owens and Stewart 1983, Thiel and Watling 1998). The initial net result is enhanced accumulation of organic matter that, through a number of feedback mechanisms, changes the nutrient dynamics of the sediment. The organic enrichment may increase oxygen consumption that, together with the reduced water exchange, result in decreased oxygen levels in both the water column and the sediment. Mineralization efficiency in the sediment is reduced due to lowering of decomposition rates with decreasing oxygen levels. The ecosystem service of converting organic particles to inorganic matter is thus reduced.

The number of species, and the density and biomass of benthic macrofauna is $40-50 \%$ lower under mature algal mats (Svensson and Pihl 2001). The impoverished community structure under algal mats is partially attributable to deteriorating oxygen conditions, but may also be a consequence of algae forming a barrier to settling larvae, thus preventing new faunal recruitment to the sediment (Olofsson 1980). Species composition of the infauna may shift in response to algal mats, resulting in dominance of tolerant opportunistic species (Norkko and Bonsdorff 1996a, b). Suspension feeders and surface deposit feeders, which are dependent on good water circulation for feeding and respiration, are drastically reduced in sediments under algal mats. Burrowing deposit feeders and predators, however, remain more or less unaffected (Fig. 1) (Österling and Pihl 2001). The loss of suspension and surface deposit feeders will dramatically decrease the capacity of the benthic system to absorb and transfer organic matter to higher trophic levels, such as fish harvested by humans (Cloern 1982, Officer et al. 1982). Further, deep-burrowing fauna are also important for sediment mineralization (Thrush and Dayton 2002) and their function may also be impaired by lower oxygen concentrations. The overall reduced efficiency of this ecosystem service will lead to an increased net accumulation of organic matter, which may reinforce the elevated nutrient load of shallow coastal systems.

Organic enrichment may also create negative impacts when algal mats are transported to deeper bottoms. Such transfer can occur continuously by water currents during the summer, but is especially evident following autumn storm events. Deeper coastal areas are sensitive to increased levels of sedimentation because the decomposition of organic matter commonly results in oxygen deficiency in the bottom water and sediments (reviewed in Diaz and Rosenberg 1995). Several fjord systems on the Swedish west coast show a significant negative trend in oxygen concentration in the bottom water over the last several decades (Rosenberg 1990), which is believed to be caused by sedimentation of excess micro- and macroalgal blooms. There is, however, a need for studies to examine such linkage in more detail.

Denitrification is another ecosystem service that is negatively affected by algal mats (Table 1). The reduced oxygenation of the sediment-water interface beneath algal mats has the potential to reduce the capacity of the denitrification process, $i$. e. the removal of dissolved inorganic nitrogen (DIN) from the system. Studies from temperate regions have shown that the rate of denitrification is reduced by an order of magnitude in sediments enriched with algae (Hansen and Blackburn 1991, Tuominen et al. 1999). The contribution of infaunal activity to increasing denitrification processes and DIN fluxes is well documented (Hansen and Kristensen 1997, Berg et al. 2001, Gilbert et al. 2003). The reduced infauna beneath algal mats can lower the denitrification rate by two mechanisms. Firstly, by reducing the amount of sediment surfaces suitable for the denitrification process, and secondly by increasing micro-phytobenthos (MPB) activity due to reduced sediment mixing. Shallow soft sediments function as sinks for nutrients, but under anoxic conditions (resulting from development of macroalgae mats) these sediments can instead become sources leaching $\mathrm{N}$ and $\mathrm{P}$ to the water column (Tyler et al. 2003). Even if both macroalgae and MPB are sinks for nitrogen, the nutrients still remain in the ecosystem (albeit transformed). Denitrification rates are between 0.060 to 1 millimol- $\mathrm{m}^{-2}-\mathrm{h}^{-1}\left(7\right.$ to $\left.123 \mathrm{~kg}-\mathrm{m}^{-2}-\mathrm{yr}^{-1}\right)$ in shallow sandy soft bottom habitats on the Swedish west coast (Sundbäck and Miles 2000, 2002), in the lower range reported from other shallow-water coastal sediments in temperate areas (Cabrita and Brotas 2000).

The economic value of reduced marine eutrophication in Swedish coastal waters and in the Baltic Sea has been estimated in several studies. Frykblom et al. (2005) reported that the benefits of a one-metre improvement in summer Secchi depth in the Stockholm archipelago would amount to SEK 
Fig. 1. Shift in species composition in response to cover by algal mats, illustrated by altered infaunal diversity (individuals per $0.01 \mathrm{~m}^{2}$ ) in different functional groups . Treatment $1=$ no algal mats; Treatment $2=480 \mathrm{~g} \mathrm{~m}^{-2}$ of algae in net bags placed somewhat above the sediment; Treatment $3=480 \mathrm{~g} \mathrm{~m}^{-2}$ of algae in cages on the sediment. Treatment 2 simulates moderate algae cover as water exchange is facilitated. (ANOVA; $\mathrm{p}<0.01$ ) (based on Österling and Pihl 2001).

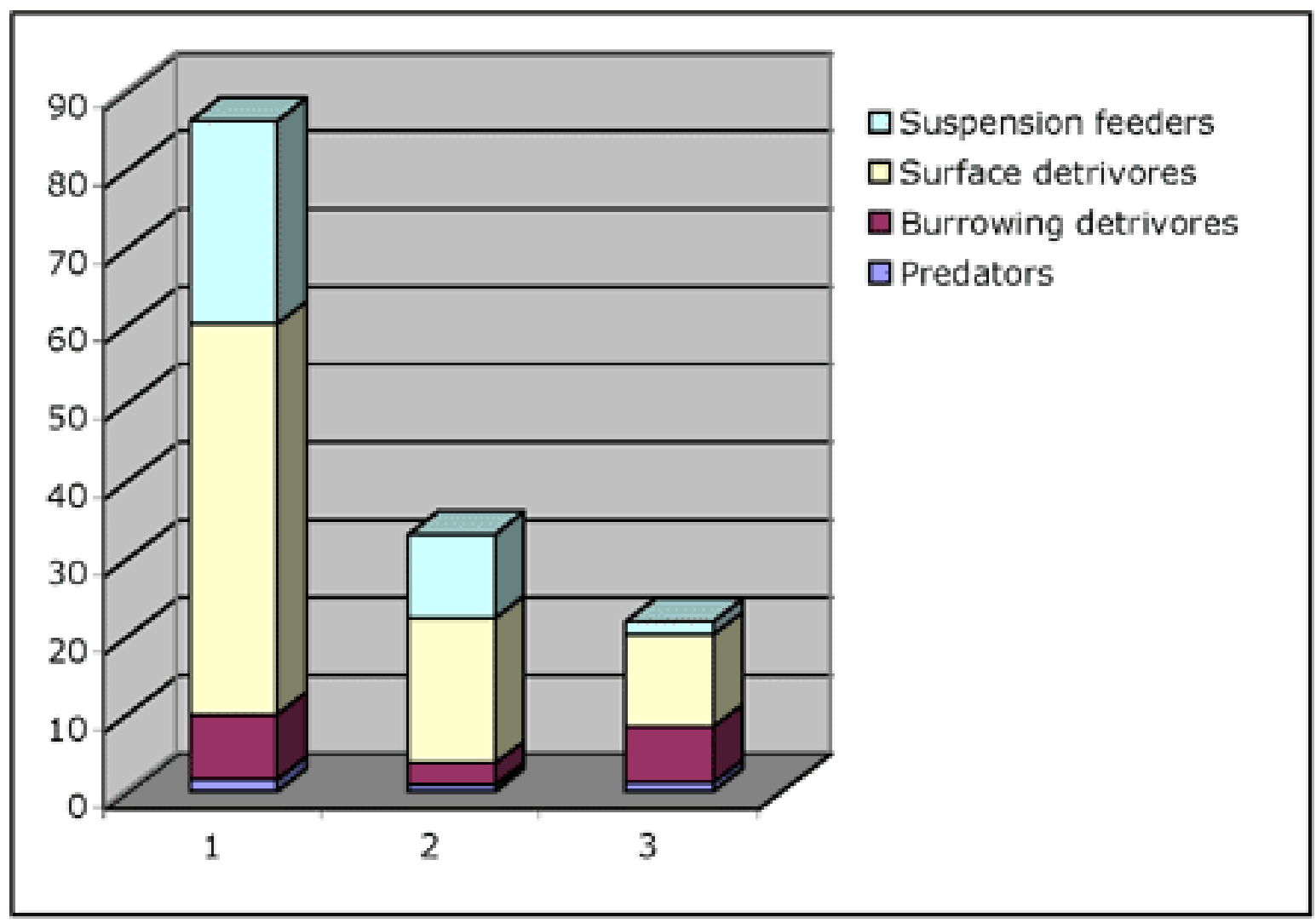

60-500 million-yr ${ }^{-1}$ (on 31 January 2005, 7 SEK was equivalent to around one USD). One might also get indications of the economic value of the denitrification service through the costs of replacing it by conventional sewage treatment or the avoidance costs that society is prepared to expend for any given nutrient reduction. For example, Gren et al. (1997) reported that the costs of removing nitrogen in conventional Swedish sewage treatment plants are about SEK $30,000 \mathrm{t}^{-1}$ of removed $\mathrm{N}$, and that new treatment technology may reduce this cost to about SEK 20,000 $\mathrm{t}^{-1}$. Such cost estimates should be compared to benefit estimates such as those mentioned above rather than being used as estimates of economic value. Attempts to carry out a costbased valuation rely on substitutability between the denitrification service and man-made alternatives, identification of cost-effective man-made alternatives, and the willingness of citizens to pay the costs (Freeman 2003, Sundberg 2004).

\section{Seafood production}

Marine shallow soft bottoms are essential habitats for many crustaceans and fish species (Sogard and Able 1991). A shift from bare sediment to algae will alter the quality and function of these habitats as nursery and feeding grounds for commercial fishery species such as flatfish, gadoids, clupeids, and salmonids (Table 1). Generally, macrovegetation such as kelp and seagrass has positive effects on 
both abundance and diversity of fish assemblages in the coastal zone (Adams 1976, Carr 1989). However, in areas where filamentous green algae becomes dominant, the number of fish species and fish biomass decreases (Pihl et al. 1995). This can be explained by: (1) the extreme density of algal mats that prevent fish larval immigration as well as adult fish migration, (2) altered or reduced food resources, and (3) reduced oxygen levels. Laboratory experiments have shown that juvenile cod actively avoid filamentous algae when offered alternative habitats (Borg et al. 1997), and that algal mats negatively affect their foraging success (Isaksson et al. 1994).

Juvenile plaice mainly feed on benthic infauna (Wennhage and Pihl 2002), a food source that is greatly reduced under algal mats. Further, exudates produced by algae in combination with low oxygen levels increase mortality rates of plaice larvae during settlement (Larson 1997). Using a numerical model, Pihl et al. (2005) studied the effects of algal mats on the recruitment of plaice. Output of juveniles from nursery grounds was reduced by $30-40 \%$ during different scenarios of larval supply to the coast (Pihl et al. 2005). Assuming that this finding is valid also for Danish nursery grounds, this reduction is likely to affect the plaice population and thus catches in the whole plaice fishery in the Kattegat and Skagerrak. In the last decade, the total catch in this fishery has been about 9,000 t-yr ${ }^{-1}$, which corresponds to a total gross income to fishermen of about SEK 180 million-yr ${ }^{-1}$ (Fiskeriverket 2001, ICES 2001). If the 30-40\% reduction in the output of juveniles ultimately results in a corresponding decrease in total catch, total gross income to fishermen would be reduced by SEK 54 to 72 million-yr ${ }^{-1}$. While a complete economic valuation of the reduction in juvenile output has to take into account several other factors - such as changes in fishermen behavior and costs nonetheless these figures illustrate the economic importance of shallow soft bottoms as a nursery.

The structural and functional properties of algal mats offer opportunities for some species associated with dense vegetation to expand their distribution. In Swedish coastal areas, the shore crab (Carcinus maenas) and fishes such as sticklebacks (Gasterosterus aculeatus and Pungitus pungitus) seem to be well adapted to the complex structure of filamentous algal mats. Early benthic stages of the shore crab utilize algal mats as a refuge from predation during settlement (Hedvall et al. 1998), and adult crabs are dominant among epibenthic species associated with algal mats (Wennhage and Pihl in press). Sticklebacks do not occupy bare sediment habitat, but are the most dominant fish species in algal mats (Wennhage and Pihl in press). Thus, a shift to an alternative state with algal mats will result in profound changes of species and functional groups among epibenthic crustaceans, as well as fishes occupying shallow soft bottom systems (Fig. 2). The provision of ecosystem goods, in terms of the production of fish species of commercial and recreational value, will be significantly reduced, as non-commercial resident fishes and crustaceans replace them.

\section{Aesthetic and recreational values}

Social and cultural ecosystem services are affected by a high-density algae state through reduced aesthetic and recreational attraction (Table 1). The visual impact of algal mats, the smell of decomposing algae, and the physical disturbance on recreational activities such as swimming and fishing, constitute a threat to the Swedish coastal tourist industry. For example, camping ground owners in the island of land in the Baltic Sea remove tons of dead red filamentous algae every year in order to keep beaches attractive to tourists. On average, the annual cost is SEK $75000 \mathrm{~km}^{-1}$ of beach (Engkvist et al. 2001, Flodqvist and Hasselström 2004). The costs of mechanical harvesting of algal mats in the northernmost municipality of the Swedish west coast have been estimated to about SEK 660,000 $\mathrm{y}^{-1}$ (Harln and Zackrisson 2001). Other studies confirm the importance of aesthetic conditions to recreationists, who put a high economic value on improved water quality and clarity in Swedish coastal waters (Sandström 1999, Frykblom et al. 2005). Similarly, people are willing to pay for improvements of general water quality on the Swedish west coast (Eggert and Olsson 2003). Effects on property values might also be significant (Leggett and Bockstael 2000, Poor et al. 2001).

\section{SYSTEM STATE AND RESILIENCE}

Many studies have investigated possible ecological effects from increased occurrence of filamentous algal mats in coastal shallow areas (e.g., Astill and Lavery 2001, Österling and Pihl 2001, and references therein), and some have attempted to 
Fig. 2. A schematic/conceptual illustration of major changes in community structure with increasing density of filamentous algae. The smoothened lines (running average) were based on 400 quantitative samples (1 $\mathrm{m}^{2}$ ) of epibenthic fauna and filamentous algae to illustrate the significant change in community structure in relation to algae (ANOSIM-test: Global $\mathrm{R}=0.751, \mathrm{p}<0.001$; Wennhage and Pihl in press).

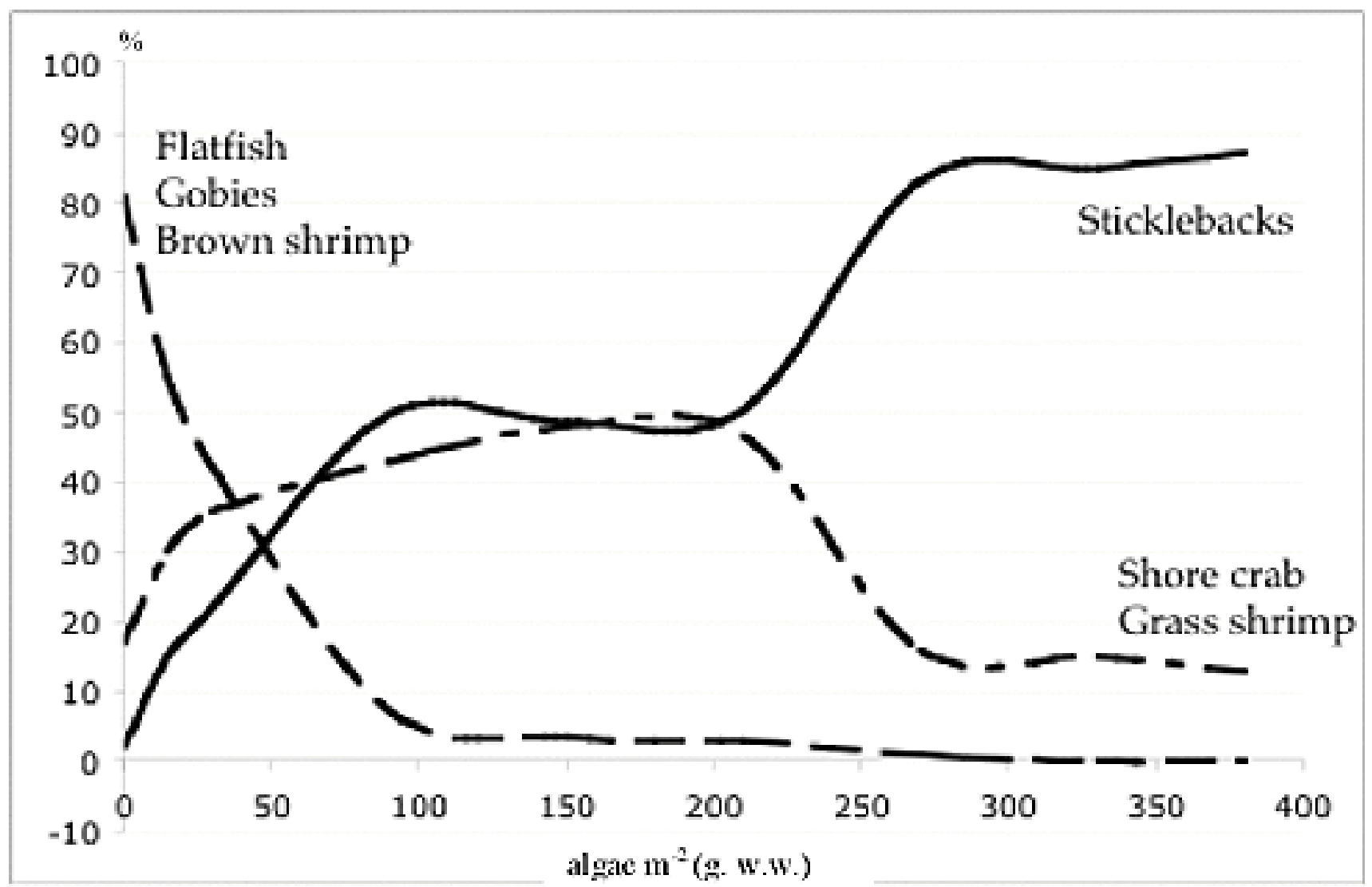

explain the underlying driving forces for their establishment (Trimmer et al. 2000, Eilola and Stigebrandt 2001) or persistence (e.g., Sundbäck et al. 2003, Tyler et al. 2003). To our knowledge, no study has interpreted the observed changes as a regime shift between two alternative states, or discussed the phenomena from a resilience perspective. This perspective is essential in order to gain a deeper understanding of system dynamics and insights into factors that should be monitored. A particular system state may be undesirable from a social perspective, i.e. by reducing the generation of beneficial goods and services (Table 1). Efforts to reverse the system to its previous state (if this is possible) may be more costly compared to intervention efforts before a shift has taken place.

As described earlier, the coastal ecosystems of the Kattegat and Skagerrak have been exposed to gradually increasing discharges of nutrients over several decades, with total input of nitrogen from land and air deposition increasing by $300 \%$ since 1940 (Rosenberg et al. 1990). The refilling of the sediment nutrient pool, together with the build-up of algal material, restrains the shallow soft bottoms into self-regenerating systems (Lavery and McComp 1991, Norkko and Bonsdorff 1996). Such an altered state of nutrient dynamics with higher recycling within shallow embayments may, therefore, initially be resilient to any efforts in 
reducing external nutrient loading to the system. Even if nutrient concentrations in coastal waters were drastically reduced by $50 \%$, the response time of changes in coverage of filamentous algae is in the order of 5 years for a $75 \%$ decrease in algae cover (Eilola and Stigebrandt 2002). Modeling with a more realistic nutrient reduction (10-20\%) resulted in a $35-50 \%$ decrease of algae cover after the same time period (Eilola and Stigebrandt 2001). Thus, none of these nutrient reduction levels resulted in complete disappearance of algae, and the self-generating characteristics of the system probably keeps it locked into a filamentous state. Eilola and Stigebrandt (2001) also identified water depth and water exchange as important factors for filamentous algae growth. Shallow bays characterized by high water turnover and wave exposure are probably more resilient against development of algae mats due to continuous transfer of organic material out of the system and re-occurring physical disturbances that inhibit algae mats.

For management purposes, it is crucial to know about the functions of both systems (with and without algae), and the controlling variables that can cause a shift between them. Shallow bays along the Swedish west coast are characterized by high benthic primary production (Sundbäck et al. 1990), high turnover rates of organic materials, and high fluxes of nutrients between sediment and overlying water. The normal state of shallow bays has been sustained for a long time despite increased coastal eutrophication. Thus, the system has been resilient against changes in increased input of organic material, i.e. the many functions within the bay have been sustained. However, the emergence of algalcovered bays indicates that the resilience of many shallow systems has been reduced (Fig. 3). The shift to an algae-dominated state and its persistence is most likely due to: (1) increased loading of organic material, (2) build-up of the sediment nutrient pool available for algae growth, and (3) an increased pool of algae propagules in the sediment. Thus, the algae state produces positive feedback that keep the system locked in.

Fig. 3. a) "Ball and cup" metaphor to illustrate a shift from one alternative state to another (redrawn from Scheffer and Carpenter 2003). The ball illustrates the soft bottom sediment community and $\mathrm{A}$ and $\mathrm{B}$ alternative states. Changes in external conditions can cause a shift from one system state to another. A slow build-up of the sediment nutrient pool (conditions) (2-3) has been the driver for a shift from unvegetated shallow soft sediments (1) to filamentous algae dominated (4). b) The transition to a system having different structures and functions leads to negative social effects.

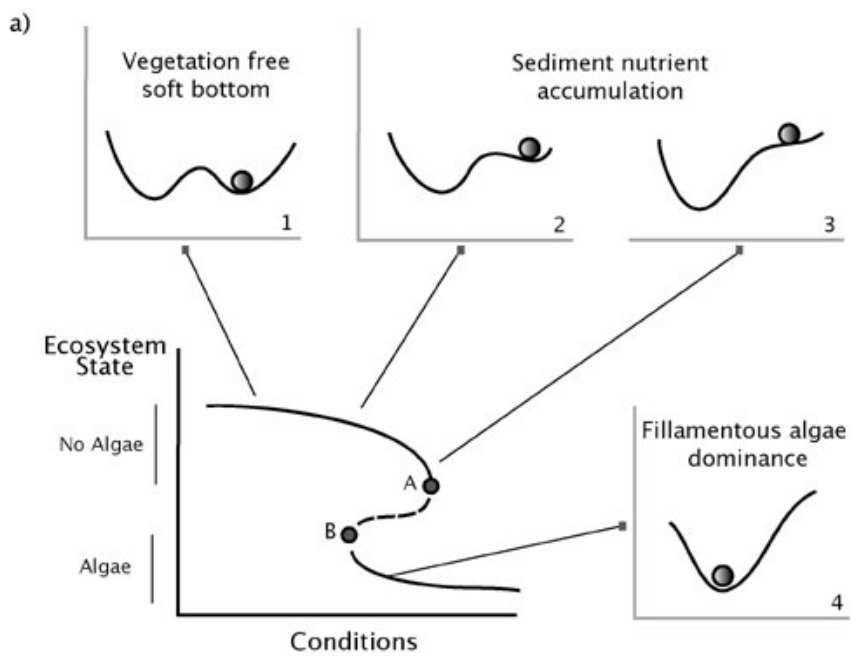

b)

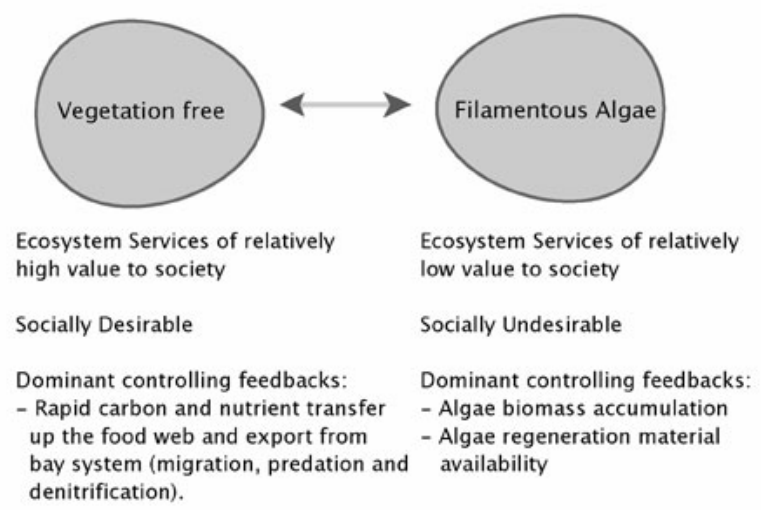

If we can estimate how organic (or nitrogen) content in the sediment has changed over time and link it to the occurrence of filamentous algae, this could be a useful parameter to monitor in the field. Even if a strong correlation between organic content and algae occurs, it may still be difficult to prevent such shifts taking place. Preventing algal mats requires nutrient reduction measures such as nitrogen removal in sewage treatment plants. However, once 
the transition to a filamentous algae dominated state has occurred, reactive measures such as mechanical removal of algal mats might have to be taken at considerably higher cost than those of preventive measures.

\section{CONCLUSIONS}

The rapid increase of filamentous algal cover in previously unvegetated shallow areas of Swedish coastal habitats may have severe negative consequences for society. This is partly because these habitats constitute important feeding and breeding grounds for commercially valuable fish species. They also sustain valuable ecosystem services by facilitating nitrogen removal through denitrification, and are important recreational areas with high aesthetic values. We suggest that the observed regime shift is driven by increased coastal eutrophication that exceeds a threshold for development of filamentous algae. Organic materials accumulate and increase the sediment nitrogen pool. The algae keep the system locked into a state with recurring algae development, by facilitating further sediment accumulation and storing algae fragments for regrowth. The alternate system seems to be resilient against restoration efforts, leading to increased costs for society.

Responses to this article can be read online at: http://www.ecologyandsociety.org/vollo/iss 1/art30/responses/

\section{Acknowledgments:}

The authors are grateful for comments on earlier versions of the manuscript by Alf Norrko and anonymous referees. The work was financed by Swedish EPA within MARBIPP programme.

\section{LITERATURE CITED}

Adams, S.M. 1976. The ecology of eelgrass, Zostera marina (L.) fish communities. I Structural analysis. Journal of Experimental Marine Biology and Ecology 22:269-291.

Afzelius, L. 1978. Tjrnarkipelagen del III Marin fauna. Cty. Göteborg Bohus 6:(65).

Astill, H., and P. Lavery. 2001. The dynamics of unattached benthic macroalgal accumulations in the Swan-Canning Estuary. Hydrological Processes 15:2387-2399.

Aure, J., D. Danielssen, and R. Saetre. 1996. Assessment of eutrophication in Skagerrak coastal waters using oxygen consumption in fjordic basins. ICES Journal of Marine Science 53:589-595.

Baden, S.P., L.O. Loo, L. Pihl, and R. Rosenberg. 1990. Effects of eutrophication on benthic communities including fish: Swedish west coast. AMBIO 19:113-122.

Berg, P., S. Rysgaard, P. Funch, and M.K. Sejr. 2001. Effects of bioturbation on solutes and solids in marine sediments. Aquatic Microbial Ecology 26:8194.

Borg, A., L. Pihl, and H. Wennhage. 1997. Habitat choice by juvenile cod (Gadus morhua L.) on sandy soft bottoms with different vegetation types. Helgolnder Meeresunters 51:197-212.

Cabrita, M.T., and V. Brotas. 2000. Seasonal variation in denitrification and dissolved nitrogen fluxes in intertidal sediments of the Tagus Estuary. Marine Ecology Progress Series 2002:51-65.

Carpenter, S.R., B. Walker, J.M. Anderies, and N. Abel. 2001. From metaphor to measurement: resilience of what to what? Ecosystems 4:765-81.

Carpenter, S.R. 2001. Alternate states of ecosystems: evidence and some implications. Pages 357-381 in Press, M.C., N. Huntly, and S. Levin, editors. Ecology: achievements and challenge. Basil Blackwell Publishing, London, England.

Carr, M.H. 1989. Effects of macroalgae assemblages on the recruitment of temperate zone reef fishes. Journal of Experimental Marine Biology and Ecology 126:59-76.

Cloern, J.E. 1982. Does benthos control phytoplankton biomass in south San Francisco Bay? Marince Ecology 9:191-202.

Dent, C. L., G. S. Cumming, and S. R. Carpenter. 2002. Multiple states in river and lake ecosystems. Philosophical transactions of the Royal Society of 
London, series B. Biological Sciences 357 (1421):635-45.

Diaz, R.J., and R. Rosenberg. 1995. Marine benthic hypoxia: A review of its ecological effects and the behavioural responses of benthic macrofauna. Oceanography Marine Biology: an Annual Review 33:245-303.

Eggert, H., and B. Olsson. 2003. Heterogeneous preferences for marine amenities: a choice experiment applied to water quality. Working paper. Göteborg University, Göteborg, Sweden.

Eilola, K., and A. Stigebrandt. 2001. Modelling filamentous algae mats in shallow bays. EU Life Algae Project, Rapport 2001:38. Lnsstyrelsen i Vstra Gtaland, Göteborg, Sweden.

Engkvist, A., T. Malm, A. Svensson, L. Asplund, M. Isaeus, L. Kautsky, M. Greger, and T. Landberg. 2001. Makroalgblomningar lngs lands kuster, effekter $p$ det lokala nringslivet och det marina ekosystemet. Report 2001:2, Kalmar University, Kalmar, Sweden.

Fiskeriverket. 2001. Betydelsen av de kvoter som str till det svenska yrkesfiskets frfogande. Report to the Swedish Government, Dnr 121-2351-00. National Board of Fisheries, Göteborg, Sweden.

Flodqvist, J., and L. Hasselström. 2004. En ekonomisk analys av rdalgsutbredningen lngs lands kust [An economic analysis of the red algae distribution along the coast of land]. Thesis. Stockholm University, Stockholm, Sweden.

Folke, C., S. Carpenter, B. Walker, M. Scheffer, T. Elmqvist, L. Gunderson, and C.S. Holling. (2005) Regime shifts, resilience and biodiversity in ecosystem management. Annual Review of Ecology Evolution and Systematics 35:557-581.

Freeman III, A. M. 2003. The measurement of environmental and resource values: theory and methods. Second Edition. Resources for the Future. Washington, D.C., USA.

Frykblom, P., H. Scharin, T. Söderqvist, and A. Helgesson. 2005. Cost-benefit analysis of coastal water quality in Sweden. In Pearce, D., R. Brouwer, editors. Cost-benefit analysis and water resources management. Edward Elgar Publishing, Cheltenham, UK.
Gibson, R.N. 1994. Impact of habitat quality and quantity on the recruitment of juvenile flatfishes. Netherlands Journal of Sea Research 32:196-206.

Gilbert, F., R.C. Aller, and S. Hulth. 2003. The influence of biogenic irrigation intensity on benthic nitrification and denitrification: an experimental and model approach. Journal of Marine Research 61(1):101-125.

Gren, I-M., T. Söderqvist, and F. Wulff. 1997. Nutrient reductions to the Baltic Sea: ecology, costs and benefits. Journal of Environmental Management 51:123-143.

Hansen, L.S., and T.H. Blackburn. 1991. Aerobic and anaerobic mineralization of organic material in marine sediment microcosms. Marine Ecology Progress Series 75:283-291.

Hansen, K., and E. Kristensen. 1997. Impact of macrofaunal recolonization on benthic metabolism and nutrient fluxes in a shallow marine sediment previously overgrown with macroalgal mats. Estuarine and Coastal Shelf Science 45:613-628.

Harln, A,. and A.-C.Zackrisson. 2001. Ekonomisk analys av algskrd och anvndning av fintrdiga alger. EU Life Algae Project, Rapport 2001:42. Lnsstyrelsen i Vstra Gtaland, Göteborg, Sweden.

Hedvall O., P.O. Moksnes, and L. Pihl. 1998. Active habitat selection by megalopae and juvenile shore crabs Carcinus maenas: a laboratory study in an annular flume. Hydrobiologia 375/376:89-100.

ICES. 2001. Report of the ICES Advisory Committee on Fishery Management. ICES Cooperative Research Report No. 246. International Council for the Exploration of the Sea, Copenhagen, Sweden.

Isaksson, I., L. Pihl, and J. van Montfrans. 1994. Eutrophication-related changes in macrovegetation and foraging of young cod (Gadus morhua L.): a mesocosm experiment. Journal of Experimental Marine Biology and Ecology 177:203-217.

Larson, F. 1997. Survival and growth of plaice (Pleuronectes platessa L.) larvae and juveniles in mats of Enteromorpha sp.: the effects of algal exudates and nocturnal hypoxia. Thesis. Göteborg University, Göteborg, Sweden. 
Lavery, P.S., and A.J. McComb. 1991. Macroalgal-sediment nutrient interactions and their importance to macroalgal nutrition in a eutrophic estuary. Estuarine, Coastal Shelf Sci. 32:28195.

Leggett, C. G., and N. E. Bockstael. 2000. Evidence of the effects of water quality on residential land prices. Journal of Environmental Economics and Management 39:121-144.

Lindahl, O. 2003. Primary production in the Gullmar fjord. Pages 20-23 in Hakansson, B., editor. Swedish national report on eutrophication status in the Kattegat and the Skagerrak, OSPAR assessment 2002, SMHI reports oceanography / Swedish Meteorological and Hydrological Institute, Stockholm, Sweden.

May, R. M. 1977. Thresholds and Breakpoints in Ecosystems with a Multiplicity of Stable States. Nature 269:471-77.

Möller, P., L. Pihl, and R. Rosenberg. 1985. Benthic faunal energy flow and biological interaction in some shallow marine soft bottom habitat. Marine Ecology Progress Series 27:109-121.

Norkko, A., and E. Bonsdorff. 1996a. Rapid zoobenthic community responses to accumulations of drifting algae. Marine Ecology Progress Series 131:143-157.

Norkko, A., and E. Bonsdorff. 1996b. Population responses of coastal zoobenthos to stress induced by drifting algal mats Marine Ecology Progress Series 140:141-151.

Officer, C.B., R.B. Briggs, J.L. Taft, L.E. Cronin, M.A. Tayler, and W.R. Boynton. 1982. Chesapeake Bay anoxia: origin, development and significance. Science 223:22-27.

Österling, M., and L. Pihl. 2001. Effects of filamentous green algal mats on benthic macrofaunal functional feeding groups. Journal of Experimental Marine Biology and Ecology 263:159-183.

Owens, N.J.P., and W.D.P. Stewart. 1983. Enteromorpha and the cycling of nitrogen in a small estuary. Estuarine and Coastal Shelf Science 17:287-296.

Petraitis, P.S., and S. R. Dudgeon. 2004. Detection of alternative stable states in marine communities. Journal of Experimental Marine Biology and Ecology 300:343-371.

Pihl, L. 1989. Abundance, biomass and production of juvenile flatfish in southeastern Kattegat. Netherlands Journal of Sea Research 24:69-81.

Pihl, L., I. Isaksson, H. Wennhage, and P-O. Moksnes. 1995. Recent increase of filamentous algae in shallow swedish bays: effects on the community structure of epibenthic fauna and fish. Netherlands Journal of Aquatic Ecology 29:349-358.

Pihl, L., J. Modin, and H. Wennhage. In press. Relating plaice recruitment to deteriorating habitat quality: effects of macroalgal blooms in coastal nursery grounds. Canadian Journal of Fish Aquatic Science.

Pihl, L., and R. Rosenberg. 1982. Production, abundance and biomass of mobile epibenthic marine fauna in shallow waters, western Sweden. Journal of Experimental Marine Biology and Ecology 57:273-201.

Pihl, L., A. Svenson, P.-O. Moksnes, and H. Wennhage. 1999. Distribution of green algal mats throughout shallow soft bottoms of the Swedish Skagerrak archipelago in relation to nutrient sources and wave exposure. Journal of Sea Research 41:281-294.

Pihl, L., and H. Wennhage. 2002. Structure and diversity of fish assemblages on rocky and soft bottom shores on the Swedish west coast. Journal of Fish Biology 61( A):148-166.

Poor, P. J., K. J. Boyle, L. O. Taylor, and R. Bouchard. 2001. Objective versus subjective measures of water clarity in hedonic property value models. Land Economics 77:482-493.

Richardson, K., and J.P. Heilman. 1995. Primary production in the Kattegat: past and present. International symposium on nutrient dynamics in coastal and estuarine environments, Helsingoer. Ophelia 41:317-328.

Rosenberg, R., R. Elmgren, S. Fleischer, P. Jonsson, G. Persson, and H. Dahlin. 1990. Marine eutrophication case studies in Sweden.

AMBIO 19:102-108. 
Rosenberg, R., I. Cato, L. Förlin, K. Grip, and J. Rodhe. 1996. Marine environment quality assessment of the Skagerrak-Kattegat. Journal of Sea Research 35:1-8.

Sandström, M. 1999. Evaluating the benefits and effectiveness of public policy. Dissertation. Stockholm School of Economics, Stockholm, Sweden.

Scheffer, M., and S.R. Carpenter. 2003. Catastrophic regime shifts in ecosystems: linking theory to observation. TREE 18(12): 648-656.

Scheffer, M., S.R. Carpenter, J. Foley, C. Folke, and B.H. Walker. 2001. Catastrophic shifts in ecosystems. Nature 413:591-96.

Sogard, S.M., and K.W. Able.1991. A comparison of eelgrass, sea lettuce macroalgae, and marsh creeks as habitats for epibenthic fishes and decapods. Estuarine and Coastal Shelf Science 33:501-519.

Sundberg, S. 2004. Replacement costs as economic values of environmental change: a review and an application to Swedish sea trout habitats. Beijer Discussion Paper Series No. 184. Beijer International Institute of Ecological Economics, The Royal Swedish Academy of Sciences, Stockholm, Sweden.

Sundbäck, K., B. Jönsson, P. Nilsson, and I. Lindström. 1990. Impact of accumulating drifting macroalgae on a shallow-water sediment system: an experimental study. Marine Ecology Progress Series 58:26174.

Sundbäck, K., and A. Miles. 2000. Balance between denitrification and microbial incorporation of nitrogen in microbial sediments, NE Kattegat. Aquatic Microbial Ecology 22:291-300.

Sundbäck, K., A. Miles, S. Hulth, L. Pihl, P. Engström, E. Selander, and A. Svenson. 2003. Importance of benthic nutrient regeneration during initiation of macroalgal blooms in shallow bays. Marine Ecology Progress Series 246:115-126.

Sundbäck, K., and A. Miles. 2002. Role of microphytobenthos and denitrification for nutrient turnover in embayments with floating macroalgal mats: a spring situation. Aquatic Microbial Ecology 30:91-101.
Svensson, A., and L. Pihl. 2001. Biologisk underskning av grunda havsvikar effekter av fintrdiga alger och skrd. Report No. 2001:47. County of Vstra Gtaland, Sweden.

Thiel, M., and L. Watling. 1998. Effects of green algal mats on infaunal colonization of a New England mud flat - long-lasting but highly localized effects. Hydrobiologia 375/376:17789.

Trimmer, M., D.B. Nedwell, D.B. Sivyer, and S. J.Malcolm. 2000. Seasonal benthic organic matter mineralization measured by oxygen uptake and denitrification along a transect of the inner and outer River Thames estuary, UK. Marine Ecology Progress Series 197:103-119.

Thrush, S.F., and P.K. Dayton. 2002. Disturbance to marine benthic habitats by trawling and dredging: implications for marine biodiversity. Annual Review of Ecology and Systematics 33:449-473.

Tuominen, L., K. Mäkelä, K.K. Lehtonen, H. Haahti, S. Hietanen, and J. Kuparinen. 1999. Nutrient fluxes, porewater profiles and denitrification in sediment influenced by algal sedimentation and bioturbation by Monoporeia affinis. Estuarine and Coastal Shelf Science 49:83-97.

Tyler, A. C., K. J. McGlathery, and I. C. Anderson. 2003. Benthic algae control sedimentwater column fluxes of organic and inorganic nitrogen compounds in a temperate lagoon. Limnology and Oceanography 48:2125-2137.

Wennberg, T. 1987. Long-term changes in the composition and distribution of the macroalgal vegetation in the southern part of Laholm Bay, south-west Sweden, during the last 30 years. Report No. 3290. Swedish Environmental Protection Agency, Stockholm, Sweden.

Wennhage, H., and L. Pihl. 2002. Fish feeding guilds in shallow rocky and soft bottom areas on the Swedish west coast. Journal of Fish Bioliogy 61 (A):207-228.

Wennhage, H., and L. Pihl. In press. From flatfish to sticklebacks: shift in assemblage structure of mobile macrofauna in relation to green macroalgal blooms.

Zijlstra, J.J. 1972. On the importance of the 
Wadden Sea as a nursery area in relation to the observation of the southern North Sea fishery resources. Symposium of the Zoological Society of London 29:233-258. 